\title{
KEBIASAAN DAN KONSUMSI PANGAN SUKU BADUY
}

\author{
(Food Habit and Consumption of Baduy Tribe) \\ Dadang Sukandar ${ }^{1 *}$ dan Eddy S. Mudjajanto ${ }^{1}$ \\ ${ }^{1}$ Departemen Gizi Masyarakat, Fakultas Ekologi Manusia, Institut Pertanian Bogor, Bogor 16680 \\ Telp: 0251-8628304/ 8621258; Fax: 0251-8625846/8622276. ${ }^{1 *}$ Email: Ipkbiner@yahoo.com
}

\begin{abstract}
ABST RACT
The objectives of the study were: (1) to analyze the socio-economic and demographic characteristics of Baduy people; (2) to understand food habits and food consumption of Baduy people. This research is an explorative and descriptive study on the socio-cultural aspects of nutrition and food system. The data required to meet the research objectives (social, economy, ecology, food habits, food consumption, health and nutritional status) were collected through a direct interview and discussion with respondents as well as a direct observation at the location of respondents. A sample size of 338 households was drawn from the population. The allocation of sample was 303 for Outer Baduy, 10 for Inner Baduy and 25 for Moslem Baduy. To obtain the data on the cultural aspects, history and socio aspect of food, in-depth interviews was conducted with 19 key persons. The household energy and nutrient intake of Outer Baduy shows that the household energy and protein intake is $3,198 \mathrm{kcal}$ and $95 \mathrm{~g}$ per capita. This energy and protein intake has surpassed the energy and protein sufficiency level (Recommended Dietary Allowances, RDA). The energy and nutrient intake in Inner Baduy households shows that the household energy and protein daily intake per capita is $952 \mathrm{kcal}$ and $17 \mathrm{~g}$. This is far below the energy and protein sufficiency (Recommended Dietary Allowances, RDA).
\end{abstract}

Keywords: sosio-cultural, nutrition, Baduy tribe, food consumption

\section{PENDAHULUAN}

Status gizi masyarakat, yang dicerminkan dari status gizi anak balita, sangat dipengaruhi oleh distribusi dan konsumsi pangan selain kondisi kesehatan. Konsumsi dan distribusi pangan sebagai akhir dari sistem pangan erat hubungannya dengan penyajian pangan yang akhirnya akan menentukan kebiasaan makan yang diadopsi masyarakat. Kebiasaan makan mencakup pemilihan, konsumsi dan penggunaan makanan yang tersedia di sekitar masyarakat. Kebiasaan makan yang ada di masyarakat biasanya dibentuk dari hasil hubungan sosial, budaya, ekonomi, dan tekanan ekologi kondisi setempat.

Sejumlah penemuan oleh para ahli menyatakan bahwa faktor sosial-budaya memiliki peran yang besar dalam menyebabkan timbulnya masalah pangan di masyarakat. Elemen budaya menciptakan kebiasaan makan yang terkadang bertentangan dengan prinsip ilmu gizi. Budaya yang berbeda memiliki peranan dan nilai yang berbeda pula terhadap makanan. Satu budaya melarang makanan tertentu, tetapi budaya lain memberi nilai yang tinggi terhadap makanan yang sama. Terdapat berbagai pembatasan, takhayul, dan larangan dalam budaya dan tempat yang berbeda di dunia.
Jika pembatasan makanan hanya diterapkan pada kelompok tertentu dalam masyarakat, dan kelompok tersebut memiliki risiko kekurangan gizi (karena berbagai hal), maka pembatasan makanan dapat menyebabkan defisiensi gizi.

Masyarakat Baduy memiliki kondisi sosial-budaya dan sistem ekologi yang khas. Hal ini juga dapat menciptakan suatu sistem yang khas terkait pangan dan gizi yang sangat menarik untuk dipelajari.

Tujuan khusus yang kegiatan penelitian ini adalah (1) Menganalisis karakteristik sosialekonomi dan demografi masyarakat Baduy dan (2) Menganalisis asupan gizi, status gizi, dan status kesehatan masyarakat Baduy.

\section{METODE}

\section{Desain, Tempat, dan Waktu penelitian}

Desain penelitian ini adalah studi deskriptif dan eksploratif terhadap aspek sosialbudaya sistem pangan dan gizi. Penelitian dilakukan pada masyarakat Baduy yang tinggal di Desa Kanekes, Kecamatan Leuwidamar, Kabupaten Lebak, Provinsi Banten. Studi ini dilakukan selama 12 bulan. 


\section{Teknik Penarikan Contoh}

Ukuran sampel sebanyak 338 rumah tangga diambil dari sekitar 2500 rumah tangga, dengan alokasi sampel sebanyak 303 untuk Baduy Luar, 10 untuk Baduy Dalam dan 25 untuk Baduy Muslim. Untuk mendapatkan data aspek budaya, sejarah dan aspek sosial pangan, wawancara mendalam dilakukan terhadap 19 orang tokoh kunci. Sampel rumah tangga diperoleh dari 13 kampung di Baduy Luar, Baduy Dalam, dan Baduy Muslim. Tokoh kunci diperoleh dari beberapa kampung di Baduy Luar, Baduy Dalam (Kampung Cibeo), Baduy Muslim (Kampung Cikakal Girang), dan tokoh kunci yang tinggal di sekitar Desa Kanekes.

Untuk memilih sampel rumah tangga, dibuat kerangka sampling dengan 13 kampung. Terdapat sekitar 12500 orang atau 2500 rumah tangga di Desa Kanekes. Kemudian, sampel rumah tangga diambil secara acak dari kerangka sampling di setiap kampung (sampel).

\section{J enis dan Cara Pengumpulan Data}

Data primer dikumpulkan melalui wawancara, observasi, dan pengukuran langsung, sedangkan data sekunder dikumpulkan melalui pencarian data yang telah ada dan pada saat penelitian. J enis data yang dikumpulkan dapat dilihat pada Tabel 1.

\section{Pengolahan dan Analisis Data}

Proses dan pengolahan data termasuk memeriksa kelengkapan data, pengkodean, mengatur struktur file, entry dan edit data. Analisis regresi dan korelasi dilakukan untuk menganalisis hubungan antara status gizi suami, istri dan anak balita dengan usia, pendapatan, pendidikan, jumlah anggota rumah tangga, pengetahuan gizi dan kemampuan baca tulis. Perhitungan nilai statistika dasar dan proporsi berdasarkan program Statistical AnaIysis Sistem (SAS). Semua data kualitatif dianalisis secara deskriptif.

\section{HASIL DAN PEMBAHASAN}

\section{Keadaan Sosio-Ekonomi dan Demografi \\ Pendidikan}

Berdasarkan hasil penelitian diketahui bahwa dari Baduy Luar, suami yang bisa membaca sebesar $32.7 \%$ dan istri sebesar $14.9 \%$ serta suami yang bisa menulis sebesar $29.9 \%$ dan istri sebesar 13.2\% Kemampuan baca tulis yang dimiliki tidak diperoleh melalui sekolah melainkan hasil pergaulan, baik dengan pendatang, teman-teman sesama orang Baduy yang mempunyai pengalaman atau banyak bergaul di luar Baduy, ataupun pekerja pemerintah yang sering berada di Baduy seperti bidan dan kader posyandu. Sementara itu, hanya sebesar $10 \%$ suami Baduy Luar yang mampu membaca

Tabel 1. Data dan metode pengumpulan data

\begin{tabular}{|c|c|}
\hline Data & Metode Pengumpulan \\
\hline \multicolumn{2}{|l|}{ A. Data Primer } \\
\hline \multicolumn{2}{|l|}{$\begin{array}{l}\text { 1. Data Sosial : } \\
\text { - Usia (kepala keluarga dan istri) } \\
\text { - Pendidikan (kepala keluarga dan istri) } \\
\text { - Ukuran rumah tangga } \\
\text { - Pekerjaan (kepala keluarga dan istri) } \\
\text { - Pengetahuan gizi }\end{array}$} \\
\hline \multicolumn{2}{|l|}{$\begin{array}{l}\text { 2. Data Ekonomi } \\
\text { - Pendapatan rumah tangga } \\
\text { - Pengeluaran pangan } \\
\text { - Pengeluaran non pangan } \\
\text { - Kepemilikan aset }\end{array}$} \\
\hline $\begin{array}{l}\text { 3. Data kebiasaan makan } \\
\text { - J enis konsumsi pangan } \\
\text { - Frekuensi konsumsi pangan }\end{array}$ & Wawancara menggunakan kuesioner \\
\hline $\begin{array}{l}\text { 4. Data status gizi: } \\
\text { - Usia dan jenis kelamin anak } \\
\text { - Berat badan } \\
\text { - Tinggi badan }\end{array}$ & $\begin{array}{l}\text { Wawancara, pengamatan } \\
\text { Penimbangan menggunakan timbangan berat badan digital } \\
\text { Pengukuran menggunakan microtoise }\end{array}$ \\
\hline \multicolumn{2}{|l|}{ B. Data sekunder } \\
\hline $\begin{array}{l}\text { 1. Data Ekologi : curah hujan, } \\
\text { ketinggian diatas permukaan laut } \\
\text { 2. Demografi dan pertanian } \\
\text { 3. Budaya dan sejarah Baduy }\end{array}$ & Sumber: Kantor pemerintah dan tinjauan pustaka \\
\hline
\end{tabular}


dan menulis sedangkan istri tidak ada yang mampu membaca/menulis sama sekali. Keadaan ini menunjukkan bahwa orang Baduy Luar lebih sering dan lebih banyak berkomunikasi dengan dunia luar sehingga kemampuan baca tulisnya lebih baik. Baduy Muslim jauh lebih banyak yang mempunyai kemampuan baca dan tulis dibanding Baduy Luar. Sejumlah 92\% suami atau istri mempunyai kemampuan baca dan tulis. Hal ini menunjukkan memang Baduy Muslim jauh lebih terbuka dan lebih maju dibanding Baduy Luar dan juga Baduy Dalam.

\section{Mata pencaharian}

Sebagian besar orang Baduy Luar mempunyai pekerjaan sebagai petani (98.6\% untuk suami dan $90.7 \%$ untuk istri). Pekerjaan lainnya adalah berdagang dan bertenun (terutama untuk istri), karena bisa dilakukan di rumah sambil mengasuh anak. Tidak banyak jenis pekerjaan yang dilakukan oleh orang Baduy karena hidupnya masih sepenuhnya mengandalkan sumberdaya alam. Demikian juga untuk Baduy Dalam, 100\% pekerjaannya adalah sebagai petani karena domisilinya jauh di daerah pedalaman sehingga tidak ada pilihan pekerjaan. Untuk Baduy Muslim lebih banyak variasi jenis pekerjaannya yaitu selain sebagai petani, ada juga yang bekerja sebagai guru, buruh atau ibu rumah tangga. Baduy muslim tinggal di daerah yang berbatasan dengan pemukiman penduduk sehingga komunikasi dengan dunia luar sering terjadi dan ikatan dengan adat Baduy sangat longgar. Mata pencaharian orang Baduy adalah berladang dengan menanam padi. Padi hanya boleh ditanam di lahan ladang kering tanpa pengairan yang disebut huma. Padi tidak boleh dijual dan harus disimpan dengan baik untuk keperluan sehari-hari. Selain ngahuma, orang
Baduy juga bertani untuk memperoleh bahan makanan tambahan. J enis tanaman yang ditanam adalah buah-buahan seperti durian, pisang, kelapa dan jagung serta umbi-umbian seperti singkong, talas dan ubi. Bibit mereka peroleh secara turun temurun yaitu dari hasil panen sebelumnya yang ditanam kembali.

\section{Pendapatan}

Pendapatan rata-rata responden terbesar diperoleh oleh masyarakat Baduy Muslim yaitu sebesar Rp $199468 \pm$ Rp 248 600, begitu juga dengan pengeluarannya yaitu sebesar $\mathrm{Rp}$ $227265 \pm$ Rp 107 255. Lebih dari separuh pengeluaran (74.2\%) digunakan untuk pangan ( $R p$ $168179 \pm$ Rp 84 534) dan sebesar 25.8\% digunakan untuk non pangan (Rp $168179 \pm \mathrm{Rp}$ 84 534). Pendapatan orang Baduy Dalam dan Luar masih lebih rendah jika dibandingkan dengan standar garis kemiskinan pemerintah ( Rp 175 000/ kapita/bulan) apalagi jika dibandingkan standar Bank Dunia (\$1/kapita/ hari). Pendapatan Baduy Muslim sudah > Rp 175 000. Kesejahteraan masyarakat Baduy, apabila hanya diukur dari pendapatannya, dapat dikatakan sangat terbatas terutama untuk menjangkau kebutuhan-kebutuhan yang sifatnya kebutuhan sekunder.

Jika kita kaji lebih jauh, maka dari Tabel 2 diketahui bahwa pengeluaran pangan yang terbesar dialokasikan responden Baduy Luar untuk membeli lauk pauk (26.0\%) dan makanan jajanan (29.5\%). Hal ini di karenakan sumberdaya alam di Baduy tidak banyak menyediakan bahan pangan yang dapat diolah sebagai lauk pauk nabati apalagi untuk lauk pauk hewani. Keadaan ini memang akan menyebabkan orang Baduy dalam memenuhi kebutuhan lauknya sangat tergantung suplai dari luar.

Tabel 2. Statistik J enis-jenis Pengeluaran Pangan dan Non Pangan di Baduy Luar, Baduy Dalam, dan Baduy Muslim per kapita per bulan

\begin{tabular}{lrrrrrr}
\hline \multirow{2}{*}{ J enis Pengeluaran } & \multicolumn{2}{c}{ Baduy Luar } & \multicolumn{2}{c}{ Baduy Dalam } & \multicolumn{2}{c}{ Baduy Muslim } \\
\cline { 2 - 7 } & \multicolumn{1}{c}{ Rp } & \multicolumn{1}{c}{ Rp } & \multicolumn{1}{c}{ Rp } & \multicolumn{1}{c}{$\%$} \\
\hline Pangan & 24699 & 26.0 & 20167 & 18.9 & 31943 & 19.0 \\
a. Lauk Pauk & 5845 & 6.1 & 1275 & 1.2 & 6246 & 3.7 \\
b. Sayuran & 2278 & 2.4 & 17 & 0.0 & 1848 & 1.1 \\
c. Buah & 28006 & 29.5 & 12268 & 11.5 & 35007 & 20.8 \\
d. Jajanan & 35761 & 37.6 & 72961 & 68.4 & 93135 & 55.4 \\
e. Lainnya & & & & & & \\
Non Pangan & 6215 & 10.5 & 100 & 4.1 & 6416 & 10.9 \\
a. Kesehatan & 5465 & 9.2 & 667 & 27.6 & 5306 & 9.0 \\
b. Pakaian & 6720 & 11.3 & 0 & 0.0 & 1333 & 2.3 \\
c. Bahan Bakar & 31352 & 52.9 & 0 & 0.0 & 34187 & 57.9 \\
d. Rokok & 2035 & 3.4 & 0 & 0.0 & 200 & 0.3 \\
e. Sumbangan & 7513 & 12.7 & 1650 & 68.3 & 11643 & 19.7 \\
f. Lainnya & & & & & & \\
\hline
\end{tabular}


Demikian juga untuk makanan jajanan, orang Baduy banyak yang tidak mempunyai keterampilan untuk membuat makanan jajanan, sehingga sepenuhnya harus membeli dari luar. Untuk kebutuhan non pangan, pengeluaran terbesarnya adalah untuk membeli rokok (52.9\%).

Lebih dari separuh contoh responden Baduy Dalam (68.4\%) dan Baduy Muslim (55.4\%) mengalokasikan pengeluaran pangannya untuk pengeluaran lainnya seperti membeli beras, minyak goreng, mie, susu, dan lain-lain. Pengeluaran non pangan untuk pakaian dan lainnya sebesar $95.5 \%$ dan hanya $4.1 \%$ dialokasikan untuk kesehatan, karena masyarakat Baduy Dalam jika sakit cukup datang ke dukun yang ada di lingkungannya. Keperluan non pangan lainnya digunakan untuk perawatan rumah dan menyirih. Keperluan orang Baduy Dalam hampir semuanya hanya untuk memenuhi kebutuhan primernya yaitu makanan dan hanya sedikit sekali kebutuhan sekundernya.

\section{Kepemilikan Aset}

Aset yang banyak dimiliki oleh warga Baduy Luar adalah tempat tidur (16.2\%), lemari pakaian (6.3\%), tungku untuk memasak $(100 \%)$, bale-bale (98\%), dan emas (5.6\%). Karena tidak diperbolehkan memakai listrik jadi masyarakat Baduy tidak mempunyai alatalat elektronik seperti televisi, tape reconder dan lain sebagainya.

Semua keluarga Baduy Dalam memiliki tungku dari tanah liat untuk keperluan memasaknya dan enam keluarga di antaranya memiliki bale-bale di depan rumahnya yang biasanya digunakan untuk menerima tamu atau untuk tempat istirahat. Aset yang lainnya tidak dipunyai karena memang secara adat kepemilikan aset-aset yang memerlukan sentuhan teknologi terutama alat elektronik tidak diperbolehkan. J ika dibandingkan dengan Baduy Dalam kondisi Baduy Muslim sangat kontras sekali, karena hampir semua rumah tangga Baduy Muslim mempunyai tempat tidur, Iemari pakaian, tungku, dan bale-bale. Hal ini karena di Baduy Muslim tidak ada larangan untuk kepemilikan aset apapun.

\section{Perumahan}

Hampir seluruh responden Baduy Luar (90.8\%) telah memiliki rumah sendiri. Rumah yang ditempati berukuran sekitar $45 \mathrm{~m}^{2}$, dengan jumlah anggota 4-5 orang. Sementara itu Baduy Dalam mendiami rumah yang lebih luas $\left(59.6 \mathrm{~m}^{2} \pm 18.25 \mathrm{~m}^{2}\right.$ ) dibandingkan orang Baduy Luar $\left(45 \mathrm{~m}^{2} \pm 15 \mathrm{~m}^{2}\right)$. Hal ini sangat logis kare- na memang di pedalaman yang dihuni oleh Baduy Dalam lahannya sangat luas di samping itu penduduknya masih sangat jarang. Untuk masyarakat Baduy Muslim rata-rata luas rumahnya $38.10 \mathrm{~m}^{2} \pm 12.42 \mathrm{~m}^{2}$. Responden Baduy Muslim yang masih tinggal bersama orang tuanya $(24 \%$ ). Selain itu rumah di Baduy Muslim mengelompok dan letaknya berdempetan satu dengan yang lain sehingga praktis mereka banyak yang tidak mempunyai halaman rumah.

Tabel 3. Sebaran Rumah Tangga di Baduy Luar, Baduy Dalam, dan Baduy Muslim menurut status dan ukuran rumah

\begin{tabular}{|c|c|c|c|c|c|c|}
\hline \multirow{2}{*}{ Status/Ukuran } & \multicolumn{2}{|c|}{ Baduy Luar } & \multicolumn{2}{|c|}{$\begin{array}{l}\text { Baduy } \\
\text { Dalam }\end{array}$} & \multicolumn{2}{|c|}{$\begin{array}{l}\text { Baduy } \\
\text { Muslim }\end{array}$} \\
\hline & $\mathbf{n}$ & $\%$ & $\mathbf{n}$ & $\%$ & $\mathbf{n}$ & $\%$ \\
\hline \multicolumn{7}{|l|}{ Status } \\
\hline a. Milik Sendiri & 275 & 90.8 & 8 & 80.0 & 19 & 76.0 \\
\hline b. Orang Tua & 23 & 7.6 & 2 & 20.0 & 6 & 24.0 \\
\hline c. Lainnya & 5 & 1.7 & 0 & 0.0 & 0 & 0.0 \\
\hline $\begin{array}{l}\text { Ukuran rumah } \\
\left(\mathrm{m}^{2}\right)\end{array}$ & \multicolumn{2}{|c|}{$45 \pm 15$} & \multicolumn{2}{|c|}{$\begin{array}{c}59.60 \pm \\
18.25\end{array}$} & \multicolumn{2}{|c|}{$\begin{array}{c}38.10 \pm \\
12.42\end{array}$} \\
\hline
\end{tabular}

Rumah orang Baduy besarnya sekitar $7 \mathrm{X}$ 5 meter dan pada umumnya terdiri atas tiga bagian, bagian luar yang disebut sosoro dan tepas, bagian tengah yang disebut imah dan musung, dan bagian dapur yang disebut parak. Semuanya disekat dengan bilik (dinding yang terbuat dari anyaman bambu). Panggung rumah orang Baduy Dalam biasanya lebih tinggi dibandingkan dengan rumah orang Baduy Luar. Dalam pembuatan rumah di Baduy Dalam dilarang menggunakan paku besi, sebagai penggantinya dipakai paseuk yaitu paku dari bambu atau kayu. Rumah Baduy Dalam hanya memiliki satu pintu, bagian dalam rumah terbagi menjadi dua bagian yaitu kamar dan ruang tamu yang menyatu dengan dapur. Letak rumah satu dengan yang lainnya saling berhadapan. Sementara itu, di Baduy Luar penggunaan paku besi dalam pembuatan rumah tidak dilarang dan pintu rumah orang Baduy Luar tidak hanya satu, tapi ada pintu depan, pintu samping dan pintu belakang. Bagian dalam rumah terbagi menjadi beberapa tempat yaitu tempat padi, ruang tamu, kamar utama, dapur. Di luar terdapat teras untuk bersantai keluarga.

Baik orang Baduy Dalam maupun Baduy Luar tidak merasa perlu ada jendela di rumahnya, karena sirkulasi udara sudah dirasa cukup dari lubang-lubang yang ada pada lantai, dinding bambu dan atap daun nira, daun kirai dan ijuk yang dianyam. Umumnya rumah Baduy tidak dilengkapi dengan jamban (WC). Hanya beberapa rumah saja di Baduy Luar yang sudah mempunyai WC di dalam rumah. Rata-rata di setiap kampung di Baduy Luar memiliki jamban 
bersama. Di sinilah mereka melakukan kegiatan mandi, mencuci baju, mencuci piring dan mencuci makanan. Untuk buang hajat mereka melakukannya di sungai yaitu di antara bebatuan sungai yang besar. Orang Baduy Dalam karena secara adat tidak boleh memiliki jamban maka mereka buang hajat di sembarang tempat terutama di ladang atau disemaksemak bagi mereka buang hajat di sungai berarti mencemari lingkungan atau mencemari sumber airnya. Sementara itu, orang Baduy Muslim seperti kebanyakan penduduk pedesaan di Indonesia lainnya mereka ada yang memiliki jamban ada juga yang buang hajatnya di sungai.

\section{Konsumsi Pangan}

\section{Pengetahuan Gizi}

Pengetahuan gizi merupakan prasyarat penting untuk terjadinya perubahan sikap dan perilaku gizi. Dengan demikian, pengetahuan gizi akan berperan untuk mewujudkan status gizi yang baik untuk seluruh anggota keluarga. Pengetahuan gizi orang-orang Baduy umumnya rendah karena masyarakat Baduy semuanya tidak bersekolah, dan tidak mempunyai akses informasi dari media elektronik ataupun media massa. Lebih dari separuh contoh Baduy Luar (89.1\%) memiliki pengetahuan gizi yang kurang dengan rata-rata skor hanya 3.2 (skala 1 - 10). Pengetahuan hanya diperoleh dari leluhurnya, sehingga terdapat kesulitan dalam upaya me- ningkatkan pengetahuan gizi masyarakat Baduy karena terbatasnya interaksi masyarakat dengan dunia luar Baduy. Seluruh orang Baduy Dalam masuk ke dalam kategori pengetahuan gizi kurang, demikian juga dengan orang Baduy Muslim namun persentasenya hanya sebesar 40\% Sebesar 89.1\% responden Baduy Luar memiliki pengetahuan gizi kurang dengan skor $\varangle 6$, sedangkan yang termasuk kategori baik hanya $0.3 \%$ dengan skor $>8$ (Tabel 4 ). Jika dibandingkan antara skor ketiga suku Baduy dapat terlihat bahwa suku Baduy Dalam memiliki nilai terendah. Ini juga dapat disebabkan karena kehidupan Baduy Dalam masih sangat mematuhi adat dan tidak tersentuh oleh kehidupan luar sehingga tidak memperoleh pengetahuan dari luar.

Tabel 5 menunjukkan jumlah orang Baduy Luar yang menjawab benar terhadap 10 tes pertanyaan pengetahuan gizi. Tes pengetahuan gizi ini mencerminkan pengetahuan gizi secara umum. Dari 10 item pertanyaan gizi, hanya satu pertanyaan yang dapat dijawab dengan benar oleh sebagian besar responden Baduy Luar yaitu pertanyaan mengenai makanan sumber kalori (nasi, jagung, umbi) harus dimakan ketika akan berladang. Pertanyaanpertanyaan lainnya yang umumnya dijawab dengan benar adalah: merokok berbahaya bagi paru-paru dan menyebabkan batuk, serta ASI sebaiknya diberikan sampai anak berusia dua tahun.

Tabel 4. Sebaran skor pengetahuan gizi di Baduy Dalam, Baduy Muslim, dan Baduy Luar

\begin{tabular}{|c|c|c|c|c|c|c|c|}
\hline \multirow{2}{*}{ Rata-rata Skor } & \multirow{2}{*}{ Kategori } & \multicolumn{2}{|c|}{ Baduy Dalam } & \multicolumn{2}{|c|}{ Baduy Muslim } & \multicolumn{2}{|c|}{ Baduy Luar } \\
\hline & & $\mathbf{n}$ & $\%$ & $\mathbf{n}$ & $\%$ & $\mathbf{n}$ & $\%$ \\
\hline$<6$ & Kurang & 10 & 100.0 & 10 & 40.0 & 270 & 89.1 \\
\hline $6-8$ & Cukup & 0 & 0.0 & 8 & 32.0 & 32 & 10.5 \\
\hline$>8$ & Baik & 0 & 0.0 & 7 & 28.0 & 1 & 0.3 \\
\hline \multicolumn{2}{|c|}{ Rata-rata skor } & \multicolumn{2}{|c|}{$1.3 \pm 0.8$} & \multicolumn{2}{|c|}{$5.7 \pm 2.7$} & \multicolumn{2}{|c|}{$3.2 \pm 1.7$} \\
\hline
\end{tabular}

Tabel 5. Persentase Responden Baduy Luar, Baduy Dalam, dan Baduy Muslim yang Menjawab Benar Tes Pengetahuan Gizi

\begin{tabular}{|c|c|c|c|c|c|c|}
\hline \multirow{2}{*}{ Pertanyaan } & \multicolumn{2}{|c|}{ Baduy Luar } & \multicolumn{2}{|c|}{ Baduy Dalam } & \multicolumn{2}{|c|}{ Baduy Muslim } \\
\hline & $\mathbf{n}$ & $\%$ & $\mathbf{n}$ & $\%$ & $\mathbf{n}$ & $\%$ \\
\hline Makanan sumber kalori harus dimakan ketika akan berladang & 261 & 86.1 & 9 & 90.0 & 20 & 80.0 \\
\hline Pangan hewani baik untuk pertumbuhan anak & 31 & 10.2 & 1 & 10.0 & 6 & 24.0 \\
\hline Ketika hamil harus makan lebih banyak & 93 & 30.7 & 1 & 10.0 & 15 & 60.0 \\
\hline Kalsium baik untuk pertumbuhan tulang dan gigi & 45 & 14.9 & 0 & 0.0 & 10 & 40.0 \\
\hline Rabun disebabkan kekurangan vitamin A & 10 & 3.3 & 0 & 0.0 & 13 & 52.0 \\
\hline Sayur dan buah dapat melancarkan buang air besar & 85 & 28.1 & 0 & 0.0 & 14 & 56.0 \\
\hline Kurang darah disebabkan kurang protein hewani dan sayuran berdaun hijau & 67 & 22.1 & 0 & 0.0 & 13 & 52.0 \\
\hline Untuk mengetahui pertumbuhan balita harus dibawa ke posyandu & 84 & 27.7 & 1 & 10.0 & 18 & 72.0 \\
\hline Merokok berbahaya bagi paru-paru dan menyebabkan batuk & 127 & 41.9 & 1 & 10.0 & 19 & 76.0 \\
\hline ASI sebaiknya diberikan sampai anak berusia 2 tahun & 155 & 51.2 & 0 & 0.0 & 14 & 56.0 \\
\hline
\end{tabular}


Hampir setengah tes pertanyaan mengenai pengetahuan gizi tidak dapat dijawab oleh responden Baduy Dalam. Pertanyaan yang dapat dijawab oleh sebagian besar (90.0\%) responden Baduy Dalam yaitu mengenai makanan sumber kalori harus dimakan ketika akan berladang. Pada Baduy Muslim, hampir semua pertanyaan dapat dijawab dengan baik.

\section{Frekuensi Makan}

Orang Baduy Luar, Dalam dan Muslim umumnya makan tiga kali sehari. Frekuensi makan orang Baduy Luar mulai dari 1 kali sampai $3 \mathrm{kali} /$ hari sehingga paling bervariasi dibandingkan dengan frekuensi makan orang Baduy Dalam atupun Baduy Muslim yang hanya 2 atau 3 kali/ hari. Tabel 6 menunjukkan bahwa hampir semua (97.7\%) orang Baduy Luar makan tiga kali per hari diikuti oleh Baduy Muslim (92\%) dan terakhir Baduy Dalam (80\%).

Tabel 6. Sebaran Rumah Tangga menurut Frekuensi Makan

\begin{tabular}{ccccccc}
\hline \begin{tabular}{c} 
Frekuensi $\begin{array}{c}\text { Makan } \\
\text { (kali) }\end{array}$ \\
\cline { 2 - 7 }
\end{tabular} & $\mathbf{n}$ & $\%$ & $\mathbf{n}$ & $\%$ & $\mathbf{n}$ & $\%$ \\
\hline 1 & 0 & 0 & 2 & 0.7 & 0 & 0 \\
2 & 2 & 20.0 & 5 & 1.7 & 2 & 8.0 \\
3 & 8 & 80.0 & 296 & 97.7 & 23 & 92.0 \\
\hline
\end{tabular}

\section{Kebiasaan Makan}

Orang Baduy umumnya makan bersama, terutama makan sore atau pagi. Hasil penelitian menunjukkan sebanyak 90\% sampai $95 \%$ orang Baduy makan sore bersama dan $75 \%$ sampai $90 \%$ makan pagi bersama. Pada pagi hari banyak yang bisa makan pagi bersama karena mereka masih berada di rumah sebelum berangkat kerja ke ladang (huma) atau tempat lainnya pada sore atau malam harinya mereka sudah kembali berada di rumah. Ditemukan hasil bahwa semakin erat dan patuh pada adat maka semakin tinggi persentase rumah tangga yang makan siang bersama. Hal ini mungkin disebabkan oleh kesibukan anggota rumah tangga yaitu semakin maju budaya semakin sibuk orang bekerja pada siang hari sehingga semakin sedikit anggota rumah tangga yang tinggal di rumah dan bisa makan siang bersama.

Separuh orang Baduy Dalam makan bersama lebih ke arah sering dilakukan karena kebiasaan yang telah mengakar, lebih dari separuh orang Baduy Luar (58.1\%) justru tidak menjawab, namun persentase terbesar kedua (16.5\%) menjawab karena sudah menjadi kebiasaan. Berbeda dengan orang Baduy Muslim, lebih dari separuhnya (64.7\%) menjawab arti makan bersama sebagai suatu kenikmatan.

Makan bersama pada tiga tipe orang Baduy umumnya dihadiri oleh seluruh anggota keluarga atau sebagian anggota keluarga. Pada Baduy Luar dan Muslim makan bersama lebih banyak dihadiri oleh semua anggota rumah tangga apabila dibandingkan dengan Baduy Dalam. Anggota keluarga dalam suatu rumah tangga orang Baduy sangat bervariasi, keluarga yang paling sederhana terdiri atas suami dan istri, sedangkan keluarga besar dapat terdiri atas suami, istri, anak, anak saudara, paman, bibi.

Mayoritas contoh menjawab bahwa menu makanan dalam rumah tangga umumnya ditentukan oleh istri. Walaupun istri yang menentukan menu tetapi yang didahulukan atau diutamakan dalam pembagian makanan adalah suami $(>72 \%$ ) seperti dapat dilihat pada Tabel 7. Prioritas makanan bagi anak relatif kecil, hanya sekitar (15.7\%), bahkan prioritas makanan bagi istri adalah yang terkecil, di bawah $2.7 \%$ Prioritas makanan bagi istri atau anak

Tabel 7. Sebaran Rumah Tangga menurut Penentu Menu atau Prioritas Makanan

\begin{tabular}{|c|c|c|c|c|c|c|c|}
\hline \multirow{2}{*}{ Pertanyaan } & \multirow{2}{*}{ Anggota Rumah tangga } & \multicolumn{2}{|c|}{ Baduy Dalam } & \multicolumn{2}{|c|}{ Baduy Luar } & \multicolumn{2}{|c|}{ Baduy Muslim } \\
\hline & & $\mathbf{n}$ & $\%$ & $\mathbf{n}$ & $\%$ & $\mathbf{n}$ & $\%$ \\
\hline \multirow{4}{*}{ Yang menentukan menu keluarga } & Istri & 6 & 60.0 & 274 & 90.4 & 18 & 72.0 \\
\hline & Suami & 4 & 40.0 & 7 & 2.3 & 5 & 20.0 \\
\hline & Anak & 0 & 0.0 & 6 & 2 & 0 & 0.0 \\
\hline & Lainnya & 0 & 0.0 & 16 & 5.3 & 2 & 8.0 \\
\hline \multirow{4}{*}{ Didahulukan jika makanan sedikit } & Istri & 0 & 0.0 & 8 & 2.7 & 1 & 4.0 \\
\hline & Suami & 2 & 20.0 & 123 & 41 & 9 & 36.0 \\
\hline & Anak & 2 & 20.0 & 47 & 15.7 & 8 & 32.0 \\
\hline & Lainnya & 6 & 60.0 & 122 & 40.7 & 7 & 28.0 \\
\hline \multirow{4}{*}{$\begin{array}{l}\text { Jika harus ada yang didahulukan, } \\
\text { maka yang diutamakan dlm } \\
\text { pembagian makanan }\end{array}$} & Istri & 1 & 11.1 & 4 & 2 & 1 & 4.0 \\
\hline & Suami & 7 & 77.8 & 167 & 85.2 & 18 & 72.0 \\
\hline & Anak & 1 & 11.1 & 12 & 6.1 & 3 & 12.0 \\
\hline & Lainnya & 0 & 0.0 & 13 & 6.6 & 3 & 12.0 \\
\hline
\end{tabular}


relatif kecil akan memberi dampak buruk terhadap status gizi anak atau ibu yang seharusnya mendapat prioritas lebih tinggi. Ibu saat hamil atau menyusui, anak yang masih kecil memerlukan perhatian khusus dalam hal mekanan untuk status gizinya.

\section{Frekuensi Konsumsi Pangan}

Sumber pangan karbohidrat terdiri atas beras, gula, mie, singkong, ubi jalar, talas dan jagung seperti dapat dilihat pada Tabel 8 . Beras dan gula merupakan pangan sumber karbohidrat yang paling sering dikonsumsi. Frekuensi konsumsi beras sekitar 2 sampai $3 \mathrm{kali} / \mathrm{hari}$, sedangkan gula sekitar 1 sampai 2 kali/hari. Bagi orang Baduy Luar dan Baduy Muslim mie merupakan pangan sumber karbohidrat kedua yang paling sering dikonsumsi yaitu sekitar 1 sampai $1.5 \mathrm{kali} / \mathrm{minggu}$, sedangkan di Baduy Dalam, mie hampir tidak pernah dikonsumsi.

Sumber protein hewani terdiri atas ikan, daging, telur, madu, mantang dan lebah seperti dapat dilihat pada Tabel 9 ikan asin merupakan makanan sumber protein hewani yang paling sering dikonsumsi, dengan frekuensi 0.68 sampai 2.4 kali/hari. Pada masyarakat Baduy
Dalam konsumsi ikan asin adalah terendah yaitu hanya 0.68 kali/ hari. Makanan sumber protein hewani lainnya dikonsumsi antara 0.1 sampai 5.4 kali/ bulan. Makanan sumber protein hewani yang relatif jarang dikonsumsi adalah daging sapi, mantang dan lebah, namun hanya dikonsumsi oleh orang Baduy Luar. Orang Baduy Luar mengonsumsi daging sapi sekitar 5 kali/tahun, sedangkan mantang dan lebah dikonsumsi sekitar 1 kali/tahun. Hal ini dimungkinkan karena terdapat kepercayaan yang melarang masyarakat Baduy unruk beternak hewan-hewan tersebut (berkaki empat). Adanya larangan memelihara hewan tidak berarti dilarang mengonsumsi daging hewan. Orang Baduy mengonsumsi daging dan ikan yang diperoleh dari hasil berburu (menangkap ikan) atau membeli di pasar. Hingga saat ini orang Baduy menilai daging sebagai makanan yang berstatus sosial tinggi sehingga hanya disajikan pada acara-acara tertentu saja, berbeda dengan ikan yang dapat disajikan kapan saja.

Makanan sumber protein nabati terdiri atas tahu, tempe, oncom, kacang tanah, buncis, petai dan jengkol seperti dapat dilihat pada Tabel 10. Tidak ada pangan sumber

Tabel 8. Frekuensi Konsumsi Pangan Sumber Karbohidrat (kali/ waktu)

\begin{tabular}{|c|c|c|c|c|c|c|c|}
\hline \multirow{2}{*}{ Pangan } & \multirow{2}{*}{ Waktu } & \multicolumn{2}{|c|}{ Baduy Dalam } & \multicolumn{2}{|c|}{ Baduy Luar } & \multicolumn{2}{|c|}{ Baduy Muslim } \\
\hline & & rataan & sd & rataan & sd & rataan & sd \\
\hline Beras & hari & 2.90 & 0.32 & 2.86 & 0.84 & 2.16 & 1.18 \\
\hline Gula & hari & 0.82 & 0.50 & 2.24 & 1.13 & 1.43 & 1.23 \\
\hline Mie & minggu & 0.00 & 0.01 & 1.05 & 3.34 & 1.52 & 2.71 \\
\hline Singkong & bulan & 2.50 & 4.55 & 4.23 & 6.52 & 7.56 & 9.78 \\
\hline Ubi Jalar & bulan & 3.02 & 5.30 & 2.29 & 4.46 & 0.65 & 1.30 \\
\hline Talas & bulan & 1.82 & 4.01 & 2.33 & 4.03 & 1.50 & 2.88 \\
\hline J agung & tahun & 21.00 & 20.07 & 9.11 & 22.45 & 7.24 & 17.04 \\
\hline
\end{tabular}

Tabel 9. Frekuensi Konsumsi Lauk Pauk Sumber Protein Hewani (kali/ waktu)

\begin{tabular}{|c|c|c|c|c|c|c|c|}
\hline \multirow{3}{*}{ Pangan } & \multirow{3}{*}{ Waktu } & \multicolumn{6}{|c|}{ Baduy } \\
\hline & & \multicolumn{2}{|c|}{ Dalam } & \multicolumn{2}{|c|}{ Luar } & \multicolumn{2}{|c|}{ Muslim } \\
\hline & & rataan & sd & rataan & sd & rataan & sd \\
\hline Ikan asin & hari & 0.68 & 0.38 & 2.39 & 1.09 & 1.29 & 1.07 \\
\hline Susu Sapi & bulan & 0.53 & 1.37 & 3.04 & 12.80 & 3.81 & 9.22 \\
\hline Ikan Pindang & bulan & 2.90 & 4.00 & 2.98 & 3.98 & 5.36 & 3.95 \\
\hline Ikan Air tawar & bulan & 2.00 & 3.91 & 1.55 & 5.95 & 3.00 & 5.28 \\
\hline Daging Ayam & bulan & 0.23 & 0.28 & 1.39 & 6.10 & 0.52 & 0.88 \\
\hline Telur & bulan & 0.30 & 0.67 & 1.21 & 6.33 & 2.85 & 5.55 \\
\hline Ikan Laut & bulan & 0.10 & 0.32 & 1.17 & 5.70 & 1.47 & 2.69 \\
\hline Madu & bulan & 0.87 & 1.82 & 1.09 & 4.74 & 0.02 & 0.10 \\
\hline Daging Sapi & tahun & 0.20 & 0.63 & 5.04 & 84.20 & 0.20 & 0.41 \\
\hline Mantang & tahun & 0.00 & 0.00 & 1.39 & 21.25 & 0.00 & 0.00 \\
\hline Lebah & Tahun & 0.00 & 0.00 & 0.91 & 4.47 & 0.00 & 0.00 \\
\hline
\end{tabular}


protein nabati yang dikonsumsi harian. Tahu dan tempe merupakan sumber protein nabati yang paling sering dikonsumsi. Kedua makanan ini dikonsumsi sekitar 0.82 sampai 1.82 kali/ minggu. Frekuensi konsumsi tahu atau tempe pada Baduy Dalam adalah terendah yaitu 0.82 kali/minggu atau bahkan lebih rendah. Makanan sumber protein nabati lainnya adalah oncom dan kacang tanah dengan frekuensi konsumsi sekitar 1.26 sampai 4.67 kali/ bulan. Makanan sumber protein nabati yang agak jarang dikonsumsi adalah buncis, petai dan jengkol. Frekuensi konsumsi kacang buncis tertinggi adalah di Baduy Muslim yaitu sekitar 125 kali/ tahun. Petai dan jengkol sangat jarang dikonsumsi di Baduy Luar yaitu hanya sekitar 3 kali/ tahun, namun di Baduy Muslim dan Baduy Dalam tergolong makanan favorit dengan frekuensi konsumsi sekitar 35 sampai 45 kali/ tahun di Baduy Muslim dan sekitar 19 kali/ tahun di Baduy Dalam.

Sayuran yang dikonsumsi orang Baduy cukup banyak terdiri atas sekitar 17 macam, antara lain daun singkong, tomat, daun pepaya, kangkung dan lain-lain seperti dapat dilihat pada Tabel 11. Tidak ada sayuran yang dikonsumsi harian. Daun singkong, tomat dan daun pepaya adalah sayuran yang paling sering dikonsumsi, ketiga sayuran ini dikonsumsi sekitar 0.12 sampai $6.68 \mathrm{kali} /$ minggu. Tomat dan daun singkong dikonsumsi dengan frekuensi tertinggi

Tabel 10. Frekuensi Konsumsi Lauk Pauk Sumber Protein Nabati (kali/ waktu)

\begin{tabular}{|c|c|c|c|c|c|c|c|}
\hline \multirow{2}{*}{ Pangan } & \multirow{2}{*}{ Waktu } & \multicolumn{2}{|c|}{ Baduy Dalam } & \multicolumn{2}{|c|}{ Baduy Luar } & \multicolumn{2}{|c|}{ Baduy Muslim } \\
\hline & & rataan & Sd & rataan & sd & rataan & sd \\
\hline Tahu & minggu & 0.82 & 0.72 & 1.82 & 2.30 & 1.04 & 1.24 \\
\hline Oncom & bulan & 1.85 & 2.97 & 1.33 & 2.67 & 4.63 & 4.82 \\
\hline Kacang Tanah & bulan & 2.33 & 5.37 & 1.26 & 3.64 & 4.67 & 7.26 \\
\hline J engkol & tahun & 19.20 & 34.05 & 2.66 & 5.93 & 45.04 & 95.15 \\
\hline
\end{tabular}

Tabel 11. Frekuensi Konsumsi Sayuran dan Buah (kali/ waktu)

\begin{tabular}{|c|c|c|c|c|c|c|c|}
\hline \multirow{2}{*}{ Pangan } & \multirow{2}{*}{ Waktu } & \multicolumn{2}{|c|}{ Baduy Dalam } & \multicolumn{2}{|c|}{ Baduy Luar } & \multicolumn{2}{|c|}{ Baduy Muslim } \\
\hline & & rataan & Sd & rataan & sd & rataan & sd \\
\hline \multicolumn{8}{|l|}{ Sayuran } \\
\hline Daun Singkong & minggu & 0.22 & 0.41 & 3.21 & 2.64 & 5.17 & 6.44 \\
\hline Tomat & minggu & 0.33 & 0.47 & 2.73 & 2.99 & 6.68 & 6.85 \\
\hline Daun Pepaya & minggu & 0.12 & 0.32 & 1.74 & 2.24 & 0.95 & 1.61 \\
\hline Kangkung & bulan & 1.50 & 2.86 & 2.93 & 7.81 & 17.85 & 25.12 \\
\hline Daun Melinjo & bulan & 0.53 & 1.37 & 2.79 & 5.41 & 4.13 & 6.96 \\
\hline Terong & bulan & 1.76 & 2.22 & 2.71 & 4.43 & 1.57 & 3.64 \\
\hline Timun & bulan & 2.73 & 3.56 & 2.46 & 5.22 & 4.68 & 6.92 \\
\hline Pepaya Muda & bulan & 2.17 & 3.06 & 2.32 & 4.73 & 3.77 & 6.35 \\
\hline Kol & bulan & 0.53 & 1.37 & 1.87 & 5.16 & 10.15 & 20.94 \\
\hline Kacang Panjang & bulan & 4.21 & 4.51 & 1.83 & 3.75 & 8.85 & 18.35 \\
\hline Bayam & bulan & 1.70 & 2.81 & 1.80 & 4.19 & 14.55 & 23.87 \\
\hline Wortel & bulan & 0.44 & 1.37 & 1.40 & 4.38 & 7.99 & 18.05 \\
\hline Melinjo & bulan & 2.70 & 2.95 & 1.37 & 2.52 & 11.99 & 24.21 \\
\hline Labu Siam & bulan & 2.28 & 2.99 & 1.17 & 2.69 & 11.62 & 24.31 \\
\hline Nangka Muda & bulan & 2.70 & 2.95 & 1.00 & 3.42 & 1.98 & 1.76 \\
\hline Sawi & tahun & 77.70 & 74.60 & 10.76 & 69.45 & 70.56 & 92.10 \\
\hline Selada & tahun & 5.20 & 16.44 & 2.46 & 23.45 & 2.08 & 10.40 \\
\hline \multicolumn{8}{|l|}{ Buah } \\
\hline Pisang & minggu & 3.95 & 2.15 & 2.87 & 2.13 & 2.34 & 2.20 \\
\hline Jeruk & bulan & 1.42 & 1.72 & 2.32 & 4.70 & 4.36 & 5.53 \\
\hline Pepaya & bulan & 1.48 & 1.69 & 2.20 & 3.92 & 1.69 & 1.87 \\
\hline Salak & tahun & 3.10 & 7.42 & 6.06 & 17.01 & 40.00 & 145.44 \\
\hline Nanas & tahun & 3.70 & 8.06 & 2.22 & 16.12 & 21.88 & 77.77 \\
\hline Mangga & tahun & 2.70 & 7.51 & 2.08 & 7.02 & 3.20 & 7.86 \\
\hline Durian & tahun & 8.60 & 16.86 & 2.05 & 3.09 & 1.08 & 0.86 \\
\hline J ambu & tahun & 12.20 & 11.08 & 1.69 & 5.60 & 87.56 & 225.62 \\
\hline Nangka & tahun & 5.20 & 8.16 & 1.49 & 5.97 & 1.56 & 4.77 \\
\hline
\end{tabular}


di Baduy Muslim yaitu sekitar 5 sampai 7 kali/ minggu, namun kedua sayuran ini dikonsumsi dengan frekuensi terendah di Baduy Luar yaitu di $0.4 \mathrm{kali} / \mathrm{minggu}$.

Buah-buahan yang dikonsumsi orang Baduy terdiri atas pisang, jeruk, pepaya, salak, nanas, mangga, durian, jambu, dan nangka. Tidak ada buah-buahan yang dikonsumsi harian seperti dapat dilihat pada Tabel 11. Pisang merupakan buah yang paling sering dikonsumsi, dengan frekuensi konsumsi sekitar 2 sampai 4 kali/minggu. Orang Baduy Dalam adalah yang paling tinggi frekuensi konsumsi pisangnya yaitu hampir 2 kali frekuensi konsumsi pisang orang Baduy Luar ataupun Baduy Muslim.

Pangan lainnya yang dikonsumsi orang Baduy antara lain terdiri atas garam krosok, kopi, garam non krosok, monosodium glutamat (vetsin), kerupuk, kecap dan lain-lain seperti dapat dilihat pada Tabel 12. Garam krosok, kopi, garam non krosok dan vetsin adalah pangan harian yang paling sering dikonsumsi dengan kisaran konsumsi antara 0.1 sampai dengan 2.5 kali/ hari.

\section{Asupan Energi dan Zat Gizi Rumah tangga Baduy Luar, Baduy Dalam, dan Baduy Muslim}

Pada Tabel 13 terlihat asupan energi dan protein rumah tangga Baduy Luar per kapita 3198 kkal dan 95 g. Asupan energi dan protein ini sudah melebihi angka kecukupan energi dan protein (Recommended Dietary Allowances, RDA). Asupan energi sudah mencapai $145 \%$ AKG dan asupan protein bahkan hampir dua kali lipat AKG. Asupan energi terutama berasal dari beras, sedangkan protein di samping bersumber dari beras juga dari kacangkacangan.

Asupan mineral juga sudah melebihi AKG, bahkan asupan fosfor sudah mencapai empat kali AKG (Tabel 20). Asupan vitamin A dan B1 sudah memenuhi AKG, sedangkan asupan vitamin C hanya memenuhi $86 \%$ AKG. Hasil estimasi asupan energi dan zat gizi di rumah tangga tersebut menunjukkan bahwa ketersediaan pangan di rumah tangga sudah mencukupi, tetapi hal ini belum menjamin ketersediaan pangan bagi semua orang karena tidak diketahui distribusi makanannya di dalam rumah tangga tersebut.

Tabel 12. Frekuensi Konsumsi Pangan Lainnya (kali/ waktu)

\begin{tabular}{|c|c|c|c|c|c|c|c|}
\hline \multirow{2}{*}{ Pangan } & \multirow{2}{*}{ Waktu } & \multicolumn{2}{|c|}{ Baduy Dalam } & \multicolumn{2}{|c|}{ Baduy Luar } & \multicolumn{2}{|c|}{ Baduy Muslim } \\
\hline & & rataan & Sd & rataan & sd & rataan & sd \\
\hline Garam Krosok & hari & 0.61 & 0.52 & 0.06 & 0.29 & 1.01 & 1.24 \\
\hline Garam Non Krosok & hari & 0.10 & 0.32 & 1.72 & 0.86 & 0.24 & 0.44 \\
\hline Monosodium Glutamat & hari & 0.73 & 0.41 & 1.36 & 0.75 & 1.27 & 1.06 \\
\hline Bakwan & minggu & 0.35 & 0.94 & 1.37 & 1.89 & 1.77 & 2.51 \\
\hline Pisang Goreng & bulan & 1.70 & 4.16 & 4.03 & 7.23 & 3.48 & 6.92 \\
\hline Tempe Goreng & bulan & 0.00 & 0.00 & 3.20 & 6.07 & 1.77 & 6.25 \\
\hline Tahu Goreng & bulan & 0.00 & 0.00 & 2.60 & 5.25 & 2.99 & 8.45 \\
\hline Mie Ayam & tahun & 0.00 & 0.00 & 3.98 & 15.63 & 0.00 & 0.00 \\
\hline
\end{tabular}

Tabel 13. Asupan Energi dan Zat Gizi Rumah Tangga per Kapita per Hari

\begin{tabular}{lcccccc}
\hline \multirow{2}{*}{ Zat Gizi } & \multicolumn{2}{c}{ Baduy Luar } & \multicolumn{2}{c}{ Baduy Dalam } & \multicolumn{2}{c}{ Baduy Muslim } \\
\cline { 2 - 7 } & Konsumsi \pm sd & \% AKG & Konsumsi \pm sd & \% AKG & Konsumsi \pm sd & \% AKG \\
\hline Energi (kkal) & $3198 \pm 2369$ & 145.1 & $952 \mathrm{kal} \pm 795.2$ & 45.5 & $780.2 \mathrm{kkal} \pm 369.3$ & 37.2 \\
Protein (g) & $95 \pm 73$ & 198.5 & $17.4 \mathrm{gr} \pm 12.4$ & 39.1 & $23.3 \mathrm{gr} \pm 9.1$ & 54.2 \\
Kalsium (mg) & $806 \pm 868$ & 147.2 & $112.8 \mathrm{mg} \pm 59.8$ & 19.8 & $393.3 \mathrm{mg} \pm 399.4$ & 74.2 \\
Phosfor (mg) & $1741 \pm 1461$ & 400.0 & $232.1 \mathrm{mg} \pm 222$ & 53.4 & $509.5 \mathrm{mg} \pm 496.7$ & 119.7 \\
Besi (mg) & $16 \pm 12$ & 101.6 & $4.3 \mathrm{mg} \pm 3.1$ & 29.4 & $5.3 \mathrm{mg} \pm 2.3$ & 35.2 \\
Vitamin A (RE) & $666 \pm 702$ & 119.3 & $265 \mathrm{RE} \pm 199$ & 46.7 & $547 \mathrm{RE} \pm 527.8$ & 102.6 \\
Vitamin B1 (mg) & $1 \pm 2$ & 100.1 & $0.2 \mathrm{mg} \pm 0.3$ & 16.8 & $2.3 \mathrm{mg} \pm 10.1$ & 226.6 \\
Vitamin C (mg) & $49 \pm 53$ & 86.6 & $37.9 \mathrm{mg} \pm 33.8$ & 66.9 & $63.5 \mathrm{mg} \pm 89.4$ & 117.5 \\
\hline
\end{tabular}


Pada Tabel 13 dapat terlihat bahwa asupan energi dan protein rumah tangga Baduy Dalam adalah $952 \mathrm{kkal} / \mathrm{kapita} /$ hari dan $17 \mathrm{~g}$. Asupan energi dan protein ini jauh di bawah angka kecukupan energi dan protein. Asupan energi hanya memenuhi 45\% AKG dan asupan protein lebih rendah lagi, hanya 39\% AKG. Sumber utama energi berasal dari beras, sedangkan sumber protein adalah beras dan kacang-kacangan. Asupan mineral juga jauh di bawah AKG, bahkan asupan kalsium hanya mencapai seperlima AKG (Tabel 20). Asupan semua vitamin tersebut jauh di bawah AKG. Asupan vitamin B1 tidak lebih dari seperlima AKG, hal ini karena konsumsi makanan hewani mereka sangat kurang.

Sementara itu asupan energi dan zat gizi rumah tangga masyarakat Baduy Muslim per kapita per harinya adalah 780 kkal dan $23 \mathrm{~g}$. Asupan energi dan protein masyarakat Baduy Muslim juga masih di bawah angka kecukupan energi dan protein. Asupan energi hanya memenuhi 37\%AKG dan asupan protein lebih tinggi, yaitu 54\% AKG. Asupan kalsium dan besi masih di bawah AKG, sedangkan asupan fosfor sudah melebihi AKG. Asupan semua vitamin tersebut sudah melebihi AKG. Sama dengan masyarakat Baduy Dalam, dengan asupan energi yang sangat rendah pada masyarakat Baduy Muslim maka peluang malnourish juga sangat besar terjadi pada anggota rumah tangga, terutama mereka yang rawan gizi (ibu hamil, bayi dan anak-anak). Ketahanan pangan (food security) rumah tangga dapat dilihat dari indikator asupan energi per kapita di bawah 70\% Pada Tabel 14 terlihat bahwa ketiga kelompok rumah tangga tergolong tidak tahan pangan (food insecure) yaitu Baduy Luar hanya 2.7\% rumah tangga Baduy Dalam sebesar $80 \%$ rumah tangga Baduy Muslim 92\% Kalau dipertimbangkan aspek mikronutrien, maka terlihat bahwa masih banyak rumah tangga yang tidak mampu memenuhi kecukupan mikronutrien.

\section{Asupan Energi dan Zat Gizi Balita Baduy Luar, Baduy Dalam, dan Baduy Muslim}

Pada Tabel 15 disajikan asupan energi dan zat gizi anak Baduy Luar. Secara kese-

Tabel 14. Klasifikasi Rumah Tangga menurut Tingkat Kecukupan Konsumsi Zat Gizi

\begin{tabular}{lcccccccccccc}
\hline \multirow{2}{*}{ Zat Gizi } & \multicolumn{3}{c}{ Klasifikasi \% AKG Baduy Dalam } & \multicolumn{3}{c}{ Klasifikasi \% AKG Baduy Muslim } & \multicolumn{3}{c}{ Klasifikasi \% AKG Baduy Luar } \\
\cline { 2 - 13 } & $<\mathbf{7 0}$ & $\mathbf{7 0 - 9 0}$ & $\mathbf{9 1 - 1 2 0}$ & $\mathbf{1 2 1}$ & $\mathbf{< 7 0}$ & $\mathbf{7 0 - 9 0}$ & $\mathbf{9 1 - 1 2 0}$ & $>\mathbf{1 2 1}$ & $<\mathbf{7 0}$ & $\mathbf{7 0 - 9 0}$ & $\mathbf{9 1 - 1 2 0}$ & $>\mathbf{1 2 1}$ \\
\hline Energi & 80.0 & 0.0 & 20.0 & 0.0 & 92.0 & 8.0 & 0.0 & 0.0 & 2.7 & 11.1 & 29.6 & 56.6 \\
Protein & 90.0 & 0.0 & 10.0 & 0.0 & 76.0 & 20.0 & 4.0 & 0.0 & 1.5 & 4.4 & 12.8 & 81.3 \\
Kalsium & 100.0 & 0.0 & 0.0 & 0.0 & 68.0 & 4.0 & 4.0 & 24.0 & 22.1 & 12.9 & 24.6 & 40.4 \\
Phospor & 60.0 & 30.0 & 0.0 & 10.0 & 56.0 & 16.0 & 0.0 & 28.0 & 0.0 & 0 & 1.6 & 98.4 \\
Besi & 100.0 & 0.0 & 0.0 & 0.0 & 100.0 & 0.0 & 0.0 & 0.0 & 29.0 & 25 & 23.0 & 23.0 \\
Vit. A & 60.0 & 40.0 & 0.0 & 0.0 & 40.0 & 16.0 & 24.0 & 20.0 & 44.2 & 11.2 & 13.0 & 31.5 \\
Vit. B & 90.0 & 0.0 & 10.0 & 0.0 & 84.0 & 8.0 & 0.0 & 8.0 & 45.8 & 23.1 & 14.7 & 16.4 \\
Vit. C & 60.0 & 10.0 & 10.0 & 20.0 & 52.0 & 8.0 & 20.0 & 20.0 & 59.4 & 12.5 & 12.2 & 16.0 \\
\hline
\end{tabular}

Tabel 15. Statistik Asupan dan Tingkat Kecukupan Energi dan Zat Gizi Balita Baduy Luar per kapita per hari

\begin{tabular}{|c|c|c|c|c|}
\hline \multirow{2}{*}{ Pengukuran } & \multirow{2}{*}{ Zat Gizi } & \multicolumn{3}{|c|}{ Statistik } \\
\hline & & $\mathbf{n}$ & rataan & sd \\
\hline \multirow{8}{*}{ Asupan } & Energi (kkal) & 111 & 1125.21 & 925.32 \\
\hline & Protein (g) & 111 & 21.44 & 19.43 \\
\hline & Kalsium (mg) & 111 & 459.10 & 1564.54 \\
\hline & Phosfor (mg) & 111 & 390.36 & 1182.07 \\
\hline & Besi (mg) & 111 & 4.99 & 6.48 \\
\hline & Vit. A (RE) & 111 & 225.95 & 367.23 \\
\hline & Vit. B1 (mg) & 111 & 1.69 & 7.87 \\
\hline & Vit. C (mg) & 111 & 15.61 & 27.42 \\
\hline \multirow{8}{*}{ Tingkat Kecukupan (\%AKG) } & Energi & 111 & 88.15 & 73.71 \\
\hline & Protein & 111 & 88.69 & 78.85 \\
\hline & Kalsium & 111 & 98.79 & 315.76 \\
\hline & Phosfor & 111 & 129.58 & 340.92 \\
\hline & Besi & 111 & 61.25 & 73.94 \\
\hline & Vit . A & 111 & 57.95 & 90.27 \\
\hline & Vit B1 & 111 & 281.83 & 1058.42 \\
\hline & Vit $C$ & 111 & 38.73 & 64.85 \\
\hline
\end{tabular}


luruhan (anak laki-laki dan perempuan), asupan energi dan protein per hari masing-masing 1125 kkal dan 21.4 gram. Kecuali besi, asupan mineral tersebut sudah memenuhi AKG. Kecuali vitamin B1, asupan vitamin tersebut masih jauh di bawah AKG.

Asupan energi dan protein anak Baduy Dalam per hari masing-masing 724 kkal dan 11.7 gram. Asupan energi anak sudah memenuhi AKG, sedangkan asupan protein hanya memenuhi $80 \%$ AKG. Asupan mineral tersebut masih jauh di bawah AKG. Asupan vitamin A dan vitamin B1 sudah memenuhi AKG, sedangkan asupan vitamin $\mathrm{C}$ masih belum memenuhi AKG. Asupan energi dan protein anak Baduy Muslim per hari masing-masing 785 kkal dan 16.5 gram. Asupan energi dan protein anak masih di bawah AKG (75-84\%AKG).

J ika diklasifikasikan menurut tingkat kecukupan konsumsi energi dan gizi, Asupan energi di bawah 70\% AKG dklasifikasikan sebagai malnourish. Pada Tabel 17 terlihat sekitar $28 \%$ anak balita tergolong malnourish. Berdasarkan asupan mineral dan vitamin tampak terlihat bahwa paling sedikit $28 \%$ anak Baduy Dalam mengalami ketidakcukupan asupan mineral dan vitamin. Sama halnya dengan anak Baduy Muslim, yaitu sekitar $68 \%$ anak balita tergolong malnourish. Berdasarkan asupan mineral dan vitamin tampak terlihat bahwa lebih dari 50\% anak Baduy Muslim mengalami ketidakcukupan asupan mineral dan vitamin.

\section{Asupan Energi dan Gizi Anak Balita Baduy Dalam, Baduy Luar, dan Baduy Muslim menurut Jenis Kelamin}

Pada Tabel 18 disajikan asupan energi dan zat gizi anak antara anak laki-laki dan perempuan. Asupan energi dan zat gizi anak perempuan Baduy Dalam sedikit lebih tinggi dibandingkan asupan pada anak laki-laki.

Kalau dilihat pemenuhan kebutuhan energi dan zat gizi, kedua kelompok gender sudah memenuhi kebutuhan energi, vitamin $A$ dan vitamin B1, tetapi belum memenuhi kebutuhan protein, mineral, dan vitamin C. Sementara itu, pada anak Baduy Luar tidak ditemukan perbedaan asupan energi dan zat gizi menurut gender. Pola pemenuhan kebutuhan energi dan zat gizi sama antara kedua jenis kelamin. Lain halnya dengan anak Baduy Muslim terlihat bahwa tidak ditemukan pola perbedaan yang jelas asupan energi dan zat gizi antara anak laki-laki dan perempuan. Kalau dilihat pemenuhan kebutuhan energi dan zat gizi, kedua kelompok gender sudah memenuhi kebutuhan kalsium, fosfor, vitamin $\mathrm{A}$, dan vitamin B1, serta vitamin $C$ pada anak laki-laki. Zat gizi lainnya belum memenuhi AKG.

Tabel 16. Statistik asupan energi dan gizi anak balita Baduy Dalam dan Baduy Muslim per kapita per hari

\begin{tabular}{lcccc}
\hline \multirow{2}{*}{ Zat Gizi } & \multicolumn{2}{c}{ Baduy Dalam } & \multicolumn{2}{c}{ Baduy Muslim } \\
\cline { 2 - 5 } & Asupan \pm sd & \% AKG & Asupan \pm sd & \% AKG \\
\hline Energi & $724.5 \mathrm{kal} \pm 400.7$ & 97.3 & $785.3 \mathrm{kal} \pm 460.1$ & 76.9 \\
Protein & $11.7 \mathrm{gr} \pm 6.3$ & 79.0 & $16.5 \mathrm{gr} \pm 13.9$ & 84.5 \\
Kalsium & $296.2 \mathrm{mg} \pm 197.8$ & 82.0 & $479.7 \mathrm{mg} \pm 553.7$ & 112.8 \\
Phosfor & $135.6 \mathrm{mg} \pm 81.7$ & 59.9 & $276.3 \mathrm{mg} \pm 309.8$ & 106.3 \\
Besi & $1.9 \mathrm{mg} \pm 2.2$ & 37.5 & $3.3 \mathrm{mg} \pm 3.2$ & 46.0 \\
Vitamin A & $534.8 \mathrm{RE} \pm 346.2$ & 152.8 & $342.6 \mathrm{RE} \pm 454.5$ & 97.4 \\
Vitamin B1 & $1.5 \mathrm{mg} \pm 1.1$ & 405.8 & $112.0 \mathrm{mg} \pm 524.4$ & 21999.5 \\
Vitamin C & $27.6 \mathrm{mg} \pm 11.6$ & 83.4 & $28.2 \mathrm{mg} \pm 61.3$ & 75.1 \\
\hline
\end{tabular}

Tabel 17. Klasifikasi Anak Balita Baduy Dalam menurut Tingkat Kecukupan Konsumsi Energi dan Gizi

\begin{tabular}{|c|c|c|c|c|c|c|c|c|}
\hline \multirow{2}{*}{ Zat Gizi } & \multicolumn{4}{|c|}{ Klasifikasi \% AKG Baduy Dalam } & \multicolumn{4}{|c|}{ Klasifikasi \% AKG Baduy Muslim } \\
\hline & $<70$ & $70-90$ & $91-120$ & $>121$ & $<70$ & $70-90$ & $91-120$ & $>121$ \\
\hline Energi & 28.6 & 14.3 & 28.6 & 28.6 & 68.0 & 0.0 & 4.0 & 28.0 \\
\hline Kalsium & 28.6 & 28.6 & 14.3 & 28.6 & 52.0 & 0.0 & 16.0 & 32.0 \\
\hline Phospor & 57.1 & 28.6 & 14.3 & 0.0 & 46.4 & 21.4 & 10.7 & 21.4 \\
\hline Vit. B & 28.6 & 0.0 & 0.0 & 71.4 & 50.0 & 0.0 & 4.2 & 45.8 \\
\hline Vit. C & 28.6 & 28.6 & 42.9 & 0.0 & 65.4 & 7.7 & 15.4 & 11.5 \\
\hline
\end{tabular}


Tabel 18. Statistik Asupan dan Tingkat Kecukupan Energi dan Gizi Balita Baduy Dalam menurut J enis Kelamin

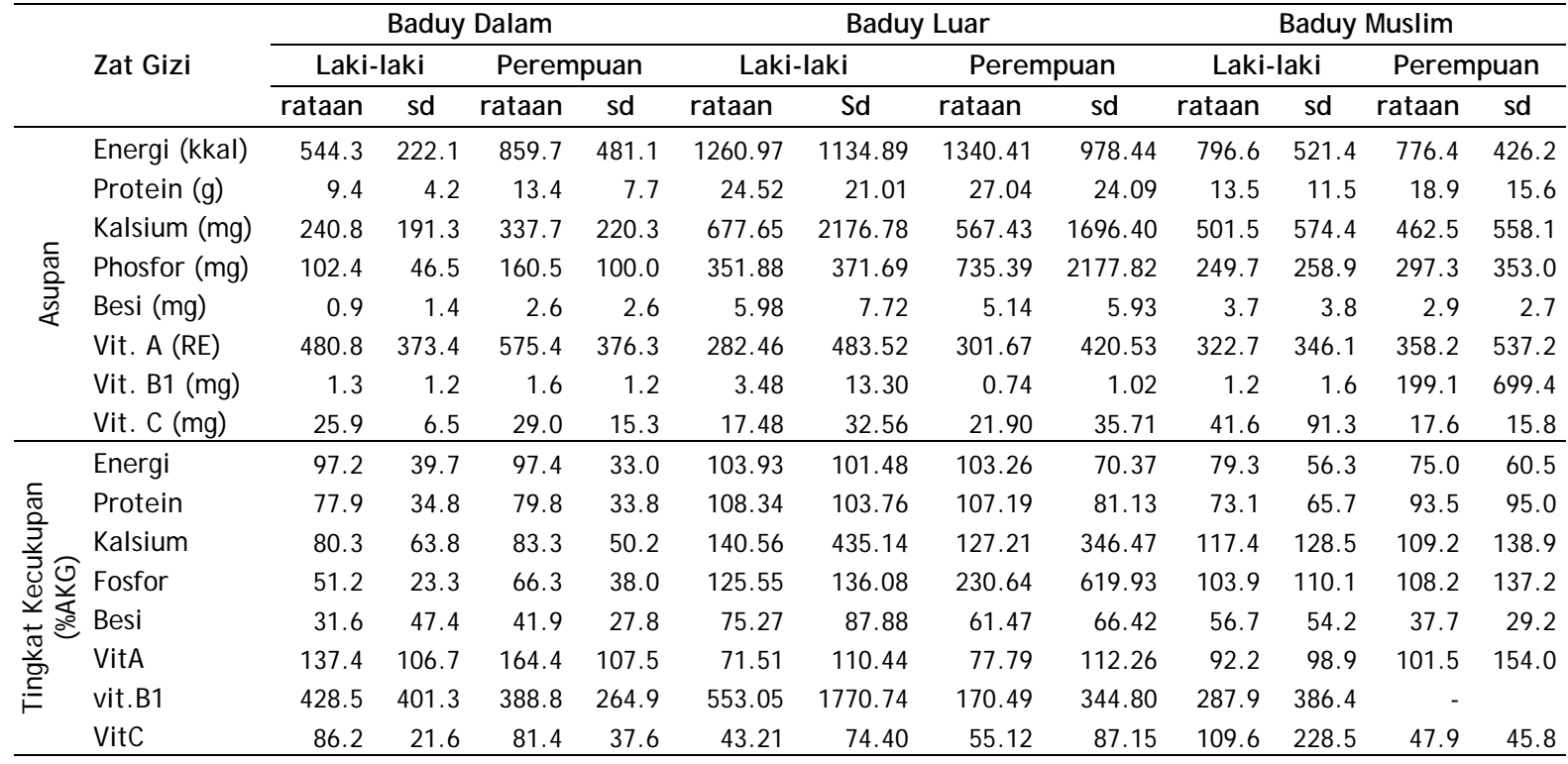

\section{KESIMPULAN}

Masyarakat Baduy adalah suatu komunitas yang hidup di wilayah pegunungan, mengisolir diri, dan memilih untuk seminimal mungkin tidak menerima pengaruh dari luar. Asupan energi dan protein rumah tangga Baduy Luar per kapita adalah $3198 \mathrm{kkal}$ dan $95 \mathrm{~g}$. Asupan energi dan protein ini sudah melebihi angka kecukupan energi dan protein (Recommended Dietary Allowances, RDA). Asupan kalsium, fosfor dan besi per kapita, masing-masing 806 $\mathrm{mg}, 1741 \mathrm{mg}$, dan $16 \mathrm{mg}$. Asupan energi dan protein rumah tangga Baduy Dalam per kapita/ hari adalah $952 \mathrm{kkal}$ dan $17 \mathrm{~g}$. Asupan energi dan protein ini jauh di bawah angka kecukupan energi dan protein (Recommended Dietary Allowances, RDA). Asupan energi hanya memenuhi 45\% AKG dan asupan protein lebih rendah lagi, hanya 39\% AKG. Asupan kalsium, fosfor dan besi rumah tangga per kapita, masingmasing $112 \mathrm{mg}, 243 \mathrm{mg}$, dan $4.3 \mathrm{mg}$. Prevalensi gizi kurang (underweight) pada anak Baduy adalah $26.4 \%$ prevalensi stunted (pendek) secara keseluruhan adalah sebesar $60.6 \%$ dan prevalensi kurus (wasted) $16.7 \%$ Prevalensi malnutrisi ini lebih tinggi daripada prevalensi tingkat nasional hasil Riskesdas 2007.

\section{DAFTAR PUSTAKA}

Hardinsyah \& Martianto D. 1988. Penilaian Kecukupan Energi dan Protein serta Kualitas Konsumsi Pangan. Wirasari, Bogor.

Idham I. 1995. Suku Baduy pada Daerah Terisolir di Provinsi Banten: Kardiovaskular juga ancaman Masyarakat Baduy. Pusat J antung Harapan Kita, J akarta.

Langdon D. 2003. Thesis: Development of Sustainable Eco-cultural Tourism in An Indigenous Community: A Case Study of the Baduy of West Java, Indonesia. School of Geography, Population and Environmental Management Flinders University, Adelaide, Australia.

Provinsi Banten. 2002. http:// www. banten. go. id/ ?link $=d t \mid \& i d=684$

Suhardjo. 1989. Sosio-Budaya Gizi. Departemen Pendidikan dan Kebudayaan. Direktorat Jenderal Pendidikan Tinggi, Pusat Pangan dan Gizi, IPB, Bogor.

Tarwotjo Ig \& Soekirman. 1987. Status Gizi Anak. Gizi Indonesia (J urnal Gizi), 12(1): $7-14$. 